\title{
Acute pseudohepatitis in a chronic substance abuser secondary to occult seat belt injury
}

\author{
Eric CS Lam MSc MD ${ }^{1}$, Rhonda M Janzen $\mathrm{MD}^{2}$, R Mark Meloche MD FRCSC ${ }^{2}$, \\ Paul J Trepanier MD FRCPC ${ }^{3}$, Eric M Yoshida MD FRCPC ${ }^{1}$
}

ECS Lam, RM Janzen, RM Meloche, PJ Trepanier, EM Yoshida. Acute pseudohepatitis in a chronic substance abuser secondary to occult seat belt injury. Can J Gastroenterol 1999;13(2): 155-158. Causes of a massive elevation in serum aminotransferases (aspartate aminotransferase [AST] and alanine aminotransferase [ALT]) in the substance-abusing patient include viral hepatitis and drug hepatotoxicity. A patient chronically addicted to injection heroin and cocaine presented to the emergency room in a confused state and was admitted to a medical ward with an AST of $4120 \mathrm{U} / \mathrm{L}$, ALT $3820 \mathrm{U} / \mathrm{L}$ and right upper quadrant discomfort. Investigations for viral and hepatotoxic causes for the liver dysfunction revealed only hepatitis $\mathrm{C}$ seropositivity. A computed tomogram of the abdomen, however, revealed a significant contusion to the right lobe of the liver consistent with traumatic injury. A motor vehicle accident, in which the patient was wearing a seat belt, and which had occurred a few days before admission and had been thought to be minor, was the cause of the liver dysfunction. Significant blunt abdominal traumatic injuries are usually managed exclusively by surgical trauma units. This case underlines the need for medical specialists to be aware of hepatic contusion injuries and to have a high index of suspicion when investigating unexplained hepatocellular dysfunction in chronic substance abusers who have been in motor vehicle accidents.

Key Words: Acute liver failure, Hepatic contusion, Substance abuse, Trauma

\section{Pseudohépatite aiguë chez un toxicomane chronique secondaire à une blessure infligée par une ceinture de sécurité}

RÉSUMÉ : Les causes d'une élévation massive des aminotransférases sériques (aspartate aminotransférase [AST] et alanine aminotransférase [ALT]) chez le toxicomane sont notamment l'hépatite virale et l'hépatotoxicité liée à la consommation de drogues. Un toxicomane adepte de l'héroine et de la cocaïne s'est présenté au service des urgences dans un état confus et aété hospital isé au service de médecine avec un taux d'AST à $4120 \mathrm{U} / \mathrm{L}$, d'ALT à $3820 \mathrm{U} / \mathrm{L}$; il se plaignait en outre d' un malaise au quadrant supérieur droit. Les examens viraux et hépatotoxiques visant à identifier une dysfonction hépatique n'ont révélé qu'une séropositivité à l'égard de l'hépatite $\mathrm{C}$. Une tomodensitométrie de l'abdomen a toutefois révélé la présence d'une importante contusion au lobe supérieur du foie, concordant avec un traumatisme. On a découvert comme cause de la dysfonction hépatique un traumatisme subi quelques jours avant son admission lors d'un accident de la route au cours duquel le patient portait sa ceinture de sécurité; or le traumatisme avait au départ semblé mineur. Les traumatismes abdominaux fermés importants sont habituellement traités exclusivement dans des unités de traumatologie chirurgicale. Ce cas rappelle la nécessité pour les spécialistes de se méfier des contusions hépatiques et de maintenir un fort degré de suspicion lorsqu'ils examinent des toxicomanes souffrant de dysfonction hépatocellulaire inexpliquée qui ont été impliqués dans des accidents de la route.

Departments of ${ }^{1}$ Medicine, ${ }^{2}$ Surgery and ${ }^{3}$ Radiology, University of British Columbia, Vancouver, British Columbia

Correspondence: Dr EM Yoshida, Division of Gastroenterology, Vancouver Hospital and Health Sciences Centre,

3300 - 950 West 10th Avenue,Vancouver, British Columbia V5Z 4E3. Telephone 604-875-5862, fax 604-875-5447

Received for publication May 20, 1998. Accepted August 28, 1998 
A $n$ acute elevation in serum aminotransferases (aspartate aminotransferase and alanine aminotransferase) in excess of $1000 \mathrm{U} / \mathrm{L}$ reflects significant hepatocellular injury, typically a consequence of acute viral hepatitis, toxic injury from medications and poisons (eg, acetaminophen overdose and isoniazid), or a hypotensive episode resulting in ischemic hepatitis (1). When investigating an acute hepatic flare of liver enzymes in the polysubstance-abusing patient, however, the clinician must also consider the psychoactive substances consumed and their route of administration as well as patterns of behaviour associated with the user's subculture. The use of injection drugs may be associated with transmission of acute, and occasionally fulminant, hepatitis B infection; coinfection or superinfection with the delta agent (2); and, rarely, acute hepatitis $\mathrm{C}$ viral $(\mathrm{HCV})$ infection $(3,4)$. The possibility of acute hepatitis A viral (HAV) infection in this subpopulation must also be considered because many injection drug users suffer from chronic viral hepatitis (5), which, in the case of $\mathrm{HCV}$, has recently been reported to be associated with an increased risk of fulminant failure during acute HAV infection (6). HAV is also well recognized to be frequently associated with lower socioeconomic class (7), which substance abusers tend to occupy. The psychoactive substances may either directly or indirectly result in acute hepatocellular injury. Cocaine use is well recognized to be associated with hepatotoxicity (8) on the basis of segmental infarction (9). The drug better known as 'ecstasy', 3,4-methylenedioxymethamphetamine, likewise, has been reported to result in acute hepatotoxicity $(10,11)$. Heavy alcohol consumption will result in the induction of the cytochrome P450 enzyme, CYP II E I, which, together with concurrent glutathione depletion, may increase the likelihood of acute acetaminophen hepatotoxicity with even therapeutic doses - 'therapeutic misadventure' (12). With these considerations in mind, we report a chronic injection drug user who recently presented to the Vancouver Hospital and

TABLE 1

Patient's serum biochem istry

\begin{tabular}{|c|c|c|c|}
\hline Laboratory test & Baseline & $\begin{array}{c}\text { On } \\
\text { admission }\end{array}$ & $\begin{array}{c}\text { Ten days } \\
\text { postdischarge }\end{array}$ \\
\hline Creatinine $(\mu \mathrm{mol} / \mathrm{L})$ & 69 & 46 & 160 \\
\hline Total bilirubin $(\mu \mathrm{mol} / \mathrm{L})$ & NA & 39 & 41 \\
\hline Alanine aminotransferase $(\mathrm{U} / \mathrm{L})$ & NA & 3820 & NA \\
\hline $\begin{array}{l}\text { Aspartate aminotransferase } \\
\qquad(\mathrm{U} / \mathrm{L})\end{array}$ & 14 & 4120 & 111 \\
\hline $\begin{array}{l}\text { Gamma-glutamyltransferase } \\
(\mathrm{U} / \mathrm{L})\end{array}$ & 18 & 15 & 359 \\
\hline Alkaline phosphatase $(\mathrm{U} / \mathrm{L})$ & NA & 137 & 209 \\
\hline International normalized ratio & NA & 1.4 & NA \\
\hline Albumin $(\mathrm{g} / \mathrm{L})$ & NA & 24 & NA \\
\hline
\end{tabular}

* Baseline values from patient's previous psychiatric admission. NA Not available
Health Sciences Centre with an acute flare in hepatocellular enzymes that was found to result from none of the indications mentioned above.

\section{CASE PRESENTATION}

A patient with a long standing addiction to both injection heroin and cocaine, chronic alcoholism and a history of a bipolar affective disorder had been an in-patient in the psychiatric unit four weeks before presentation to the author's centre. The patient was discharged with a prescription for lithium carbonate, chloral hydrate, torazepam and clonazepam. After discharge, the patient resumed use of cocaine and heroin, and was involved in a motor vehicle accident. The patient did not seek medical attention and denied any significant injury except for fatigue, anorexia and right upper quadrant abdominal discomfort. For these symptoms, the patient took acetaminophen. The day before admission, the patient was visited by the family physician who found the patient lethargic and unable to move out of bed. The patient was certified under the Mental Health Act of British Columbia (13) because of a concern for potential selfharm and was taken to hospital.

In the emergency room, the patient was noted to be disheveled, with dried blood under the fingernails but no evidence of bleeding, and alert but disoriented with respect to place and time. Chest examination was unremarkable; there was no bruising or tenderness, and auscultation was unremarkable. Physical examination did not reveal any stigmata of chronic liver disease or abdominal bruising. The liver was enlarged, $8 \mathrm{~cm}$ below the coastal margin at the midclavicular line and mildly tender to palpation. The rest of the examination was unremarkable, and a fecal occult blood test was negative. Laboratory investigations revealed a serum alanine aminotransferase level of $3820 \mathrm{U} / \mathrm{L}$ (normal less than $55 \mathrm{U} / \mathrm{L}$ ), aspartate aminotransferase $4120 \mathrm{U} / \mathrm{L}$ (normal less than $38 \mathrm{U} / \mathrm{L}$ ), total bilirubin $39 \mu \mathrm{mol} / \mathrm{L}$ (normal less than $22 \mu \mathrm{mol} / \mathrm{L}$ ), gamma-glutamyltransferase $15 \mathrm{U} / \mathrm{L}$ (normal less than $50 \mathrm{U} / \mathrm{L}$ ), alkaline phosphatase $137 \mathrm{U} / \mathrm{L}$ (normal less than $125 \mathrm{U} / \mathrm{L}$ ), international normalized ratio 1.4 (normal 0.8 to 1.2 ), albumin $24 \mathrm{~g} / \mathrm{L}$ (normal 35 to $45 \mathrm{~g} / \mathrm{L}$ ) and serum creatinine $469 \mu \mathrm{mol} / \mathrm{L}$ (normal greater than $110 \mu \mathrm{mol} / \mathrm{L}$ ) (Table 1). A chest radiograph was unremarkable. Urinalysis revealed trace opiates. A drug and toxin screen was negative for ethanol and acetaminophen.

The patient was admitted to the general medical service with a diagnosis of acute liver disease and prerenal failure. Acetylcysteine by infusion was administered because the possibility of acetaminophen toxicity could not be excluded. Viral serology was ordered and was negative for HAV immunoglobulin $\mathrm{M}$, and hepatitis B surface antigen and core antibody. Serology for HCV, which was negative seven months previously, was reactive. Renal function improved with intravenous fluids. Mental function also improved shortly after admission, and the patient denied significant acetaminophen use, alcohol consumption and illegal drug use other than habitual cocaine and heroin use. The only event that had occurred between the two hospital admissions was the 


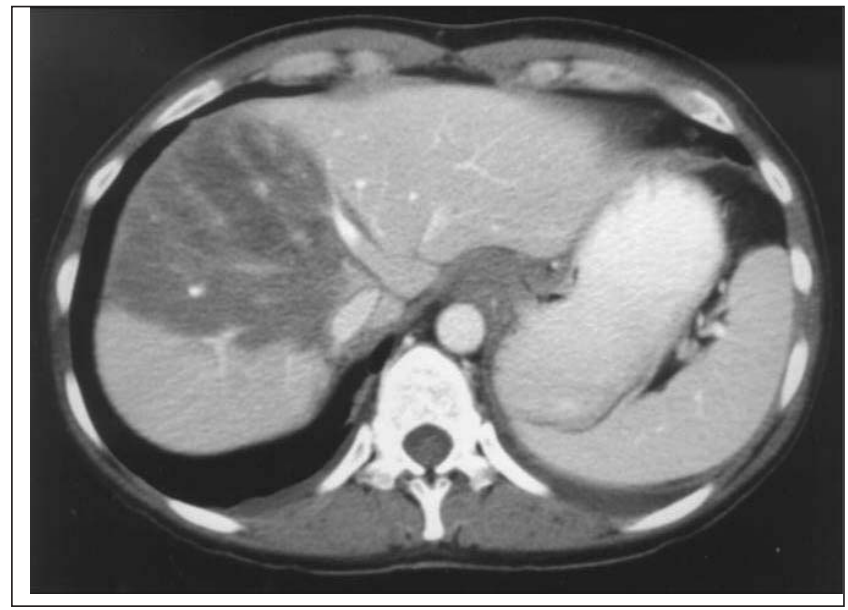

Figure 1) Representative section of the patient's abdominal computed tomogram revealing echodensity in hepatic segment 8 and in a small portion of segment 7 of the right lobe that is consistent with contusion injury. The complete computed tomogram revealed involvement of hepatic segments 5, 8 and part of 7

motor vehicle accident, which occurred five days before presentation and from the history appeared minor, especially because the patient was wearing a seat belt.

The pattern of liver enzymes improved although cholestatic enzyme levels elevated later, with alkaline phosphatase level increasing to $209 \mathrm{U} / \mathrm{L}$ and $359 \mathrm{U} / \mathrm{L}$. An abdominal ultrasound revealed an apparent complex intrahepatic mass. A computed tomogram (CT) of the abdomen revealed a small subcapsular hepatic hematoma and significant echodense changes in the right lobe, specifically in hepatic segments 5, 8 and a portion of segment 7 (Couinaud classification) (Figure 1). The hepatic vascular architecture appeared to be preserved without mass effect. The CT findings were consistent with a hepatic contusion injury. There was also decreased enhancement of the right kidney parenchyma consistent with a coincident renal contusion.

The patient remained clinically stable and was discharged after two weeks of hospitalization. Ten days postdischarge, (approximately four weeks after the motor vehicle accident), the patient experienced hematemesis but remained hemodynamically stable. Hemobilia was suspected; however, emergency esophagogastroduodenosopy did not reveal any evidence of hemobilia or any other source of bleeding. An abdominal arteriogram did not reveal active bleeding or evidence of pseudoaneurysm. A follow-up abdominal CT scan revealed some resolution of the hepatitic contusion, and the patient was discharged.

\section{DISCUSSION}

Blunt injury to the liver occurs in a reported $55 \%$ of severe and fatal motor vehicle accidents (14), with the most common source of injury arising from seat belt trauma or steering wheel impact $(14,15)$. Following a contusive injury, there is typically a massive rise in serum aminotransferase levels (16). The massive elevation in serum aminotransferase levels may, in some cases, also reflect an ischemic hepatitis from
TABLE 2

Grading of liver contusion injuries according to the American Association for the Surgery of Trauma Organ Injury Scaling Comm ittee

\begin{tabular}{|c|c|c|}
\hline Grade & Injury & Description \\
\hline \multirow[t]{2}{*}{1} & Hematoma & $\begin{array}{l}\text { Subcapsular, nonexpanding, occupies less } \\
\text { than } 10 \% \text { surface area }\end{array}$ \\
\hline & Laceration & $\begin{array}{l}\text { Nonbleeding capsular tear, less than } 1 \mathrm{~cm} \\
\text { in parenchymal depth }\end{array}$ \\
\hline \multirow[t]{2}{*}{ II } & Hematoma & $\begin{array}{l}\text { Subcapsular - nonexpanding } 10 \% \text { to } 50 \% \\
\text { surface; intraparenchymal - less than } 2 \mathrm{~cm} \\
\text { diameter }\end{array}$ \\
\hline & Laceration & $\begin{array}{l}\text { Capsular tear, active bleeding, } 1 \text { to } 3 \mathrm{~cm} \\
\text { parenchymal depth, } 10 \mathrm{~cm} \text { in size }\end{array}$ \\
\hline \multirow[t]{2}{*}{ III } & Hematoma & $\begin{array}{l}\text { Subcapsular - more than } 50 \% \text { surface area } \\
\text { or expanding; rupture with bleeding; } \\
\text { intraparenchymal - more than } 2 \mathrm{~cm} \text { or } \\
\text { expanding }\end{array}$ \\
\hline & Laceration & More than $3 \mathrm{~cm}$ parenchymal depth \\
\hline \multirow[t]{2}{*}{ IV } & Hematoma & Intraparenchymal rupture - active bleeding \\
\hline & Laceration & Disruption involving $25 \%$ to $50 \%$ of lobe \\
\hline \multirow[t]{2}{*}{ V } & Laceration & $\begin{array}{l}\text { Parenchymal disruption more than } 50 \% \text { of } \\
\text { lobe }\end{array}$ \\
\hline & Vascular & $\begin{array}{l}\text { Juxtahepatic injuries (venacava, hepatic } \\
\text { veins) }\end{array}$ \\
\hline VI & Vascular & Avulsion \\
\hline
\end{tabular}

Data adapted from reference 19

hemorrhagic shock due to the effects of the multitraumatic injury $(17,18)$. The hepatic injuries produced by abdominal trauma are typically hematomas that may be subcapsular or intraparenchymal, laceration of the capsule, parenchymal disruption to varying degrees and injury to the vascular structures including avulsion (19). A scale incorporating these features and their severity has been adopted by the American Association for the Surgery of Trauma Organ Injury Scaling Committee (19) to grade the extent of hepatic injury (Table 2), which has both prognostic and therapeutic implications. The most feared complications of hepatic contusion injuries are capsular rupture and sudden massive hemorrhage. Other complications include gastrointestinal bleeding from hemobilia; intraparenchymal hemorrhage into necrotic tissue, which is rarely exsanguinating; formation of bilomas; and biliary duct obstruction $(20,21)$.

The approach to managing hepatic contusion injuries has changed over the past few decades. Previously, surgical exploration or diagnostic peritoneal lavage was considered mandatory for all patients and is clearly appropriate if there is hemodynamic compromise or high risk injury on diagnostic imaging. Definitive surgical management may include hepatotomy with ligation and/or repair of damaged vessels, resection, lobectomy, debridement and perihepatic packing 
with drainage (17). Rarely, liver transplantation has been undertaken for traumatic injury, accounting for only $0.1 \%$ of adult transplants (eight of 9347) in the United Network of Organ Sharing from 1987 to 1993 (22). The practice of selective nonoperative conservative management with vigilant monitoring and supportive care originates from the experience with pediatric trauma victims (23). Recent reports have suggested that selected hepatic contusion injuries may improve with regular monitoring, including serial CT scans over several months without the need for surgery $(24,25)$. Radiological interventions such as angiography and embolization may also be successful in both the diagnosis and management of vascular leaks and aneurysm formation (26-27). Although grade I to III injuries are often hemodynamically stable, the surgical versus nonsurgical management approach depends on the clinical situations including the presence or absence of coincidental traumatic injuries. Certainly, a surgical consultation is required in most, and probably all, cases of hepatic contusion injury because higher grade injuries (ie, grades III to V) must be assessed on an individual basis and require careful evaluation by those familiar with this type of injury.

Our patient's experience is interesting in that the history and the lack of physical findings, specifically the absence of sternal steering wheel injury, abdominal bruising or orthopedic injuries, suggested that the motor vehicle accident was minor. The apparent lack of concern about the accident and

\section{REFERENCES}

1. Yoshida EM, Steinbrecher UP. Interpreting liver enzymes. A practical guide for clinical use. Consultant 1997;37:569-77.

2. Smedile A, Farci P, Verme G, et al. Influence of delta infection on severity of hepatitis B. Lancet $1982 ; 1 i: 945-7$.

3. Gordon FD, Anastopoulos H, Khettry V, et al. Hepatitis C infection: a rare case of fulminant hepatic failure. Am J Gastroenterol $1995 ; 90: 117-20$.

4. Farci P, Alter HI, Shimoda A, et al. Hepatitis C virus-associated fulminant hepatic failure. N Engl J Med 1996;335:631-4.

5. Guidagnino V, Zimatore G, Izzi A, et al. Relevance of intravenous cocaine use in relation to prevelance of HIV, hepatitis $B$ and $C$ virus markers among intravenous drug abusers in southern Italy. J Clin Lab Immunol 1995:47:1-9.

6. Vento S, Garofano T, Renzini C, et al. Fulminant hepatitis associated with hepatitis A virus superinfection in patients with chronic hepatitis C. N Engl J Med 1998;338:286-90.

7. Lavine JE, Bull FG, Millward-Sadler GH, Arthur MJP. Acute viral hepatitis. In: Millward-Sadler GH, Wright R, Arthur MJP, eds. Wright's Liver and Biliary Disease, 3rd edn. Philadelphia: WB Saunders Company, 1992:681-786.

8. Perino LE, Warren GH, Levine JS. Cocaine-induced hepatotoxicity in humans. Gastroenterology 1987;93:176-80.

9. Wanless IR, Dore S, Gopinath N, et al. Histopathology of cocaine hepatotoxicity. Report of four patients. Gastroenterology $1990 ; 98: 497,501$.

10. Henry JA, Jeffreys KJ, Dawling S. Toxicity and deaths from 3,4-methylenedioxymethamphetamine. Lancet $1992 ; 340 \div 384-7$.

11. Khakoo SI, Coles CJ, Armstrong JS, Barry RE. Hepatotoxicity and accelerated fibrosis following 3,4-methylenedioxymetamphetamine ("ecstasy") usage. J Clin Gastroenterol 1995;20:244-7.

12. Zimmerman HJ, Maddrey WC. Acetaminophen (paracetamol) hepatotoxicity with regular intake of alcohol: analysis of instances of therapeutic misadventure. Hepatology 1995;22:767-73.

13. Mental Health Act, Revised Statutes of British Columbia 1979 , chapter 256, session 20(3). the history of polysubstance abuse led to an initial 'medical' investigation of the elevation in serum aminotransferase levels. Inadvertent acetaminophen hepatotoxicity was considered, and acetylcysteine empirically administered, despite the lack of a compatible history and a negative acetaminophen screen because these findings can be falsely negative (28). The possibility of acute HCV was also considered; however, given the normal liver observed one month before presentation and the CT scan revealing a classic liver parenchymal injury, acute HCV was highly unlikely. The true etiology of the 'pseudohepatitis' was the occult hepatic contusion from the seat belt injury during the motor vehicle accident. We suspect that use of psychoactive substances, including the benzodiazepines prescribed after the psychiatric hospitalization, contributed to lack of perception of the true extent of the traumatic injuries and may have been a contributing factor in the motor vehicle accident itself. Usually, patients with known abdominal trauma are referred to and managed by the surgical trauma services exclusively and are rarely primarily referred to medical or gastroenterological services. Our experience underlines the need for medical specialists to be aware of hepatic contusion injuries as a cause of liver dysfunction and the need for diagnostic imaging in these cases. The present case adds another entity - occult trauma - to the list of differential diagnoses of acute massive serum aminotransferase elevations in the chronic substance abusing population.

14. Arajarvi E, Santavirta S, Tolonen J. Abdominal in juries sustained in severe traffic accidents by seatbelt wearers. J Trauma 1987;27:393-7.

15. Appleby JP, Nagy AG. Abdominal injuries associated with the use of seatbelts. Am J Surg 1989;157:457-8.

16. Turril FL, Donovan AJ, Facey FL. Traumatic hepatic sequestra. Am J Surg 1971;122:175-82.

17. Wilson RH, Moorehead RJ. Hepatic trauma and its management. Injury 1991:22:439-45.

18. Pachter LH, Feliciano DV. Complex hepatic injuries. Surg Clin N Am 1996:76:763-82.

19. Pachter LH, Hofstetter SR. The current status of nonoperative management of adult blunt hepatic injuries. Am J Surg $1995 ; 169: 442.54$.

20. Gates JD. Delayed hemorrhage with free rupture complicating the nonsurgical management of blunt hepatic trauma: a case report and review of the literature. J Trauma 1994;36:572-5.

21. Durham RM, Buckley J, Keegan M, Fravell S, Shapiro MJ, Mazuski J. Management of blunt hepatic injuries. Am J Surg 1992;164:477-81.

22. Belle SH, Beringer KC, Detre KM. Liver transplantation in the United States: results from the national Pitt.UNOS liver transplant registry. In: Terasaki PI, Cecka JM, eds. Clinical Transplants 1994. Los Angeles: UCLA T issue Typing Laboratory, 1994:19-35.

23. Cywes S, Rode H, Millar AJW. Blunt liver trauma in children: nonoperative management. J Pediatr Surg 1985;20:14-8.

24. Knudson MM, Lim RC Jr, Oakes DD, Jeffrey RB Jr. Nonoperative management of blunt liver injuries in adults: the need for continued surveillance. J Trauma 1990;30:1494-1500.

25. Jeffrey RB Jr, Olcott EW. Imaging of blunt hepatic trauma. Radiol Clin North Am 1991;29:1299-310.

26. Suimoto K, Horiike S, Hirata M, Ohwada T, Maekawa K. The role of angiography in the assessment of blunt liver injury. Injury $1994: 25: 283-7$.

27. Lutzker LG. Radionuclide imaging of the injured spleen and liver. Semin Nucl Med 1983;13:184-98.

28. Schiødt FV, Rochling FA, Casey DL, Lee WM. Acetaminophen toxicity in an urban county hospital. N Engl J Med 1997;337:1112-7. 


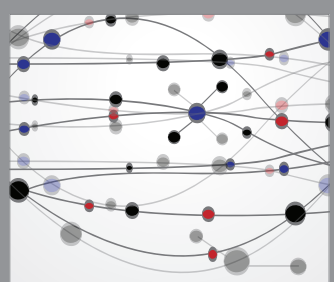

The Scientific World Journal
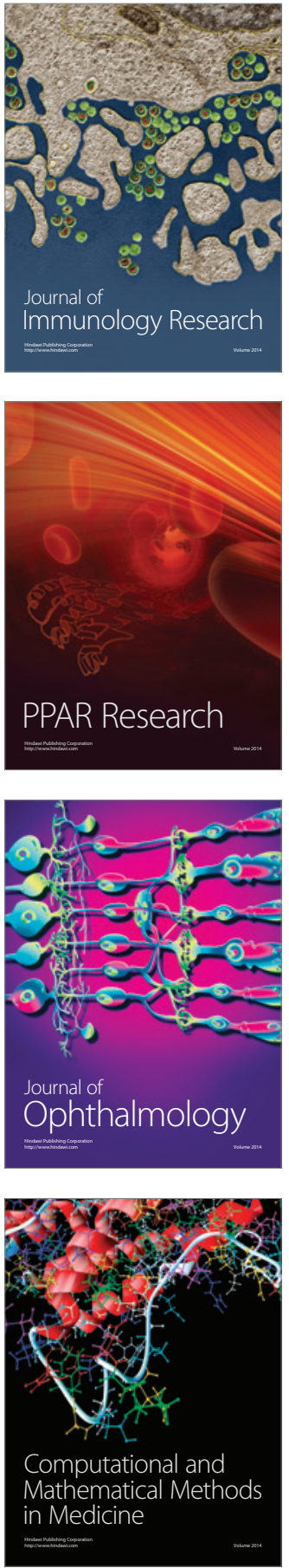

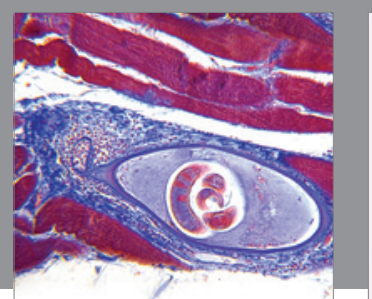

Gastroenterology Research and Practice

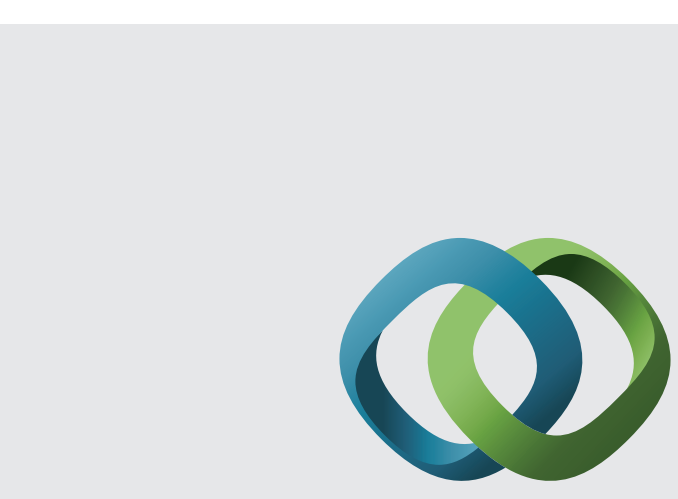

\section{Hindawi}

Submit your manuscripts at

http://www.hindawi.com
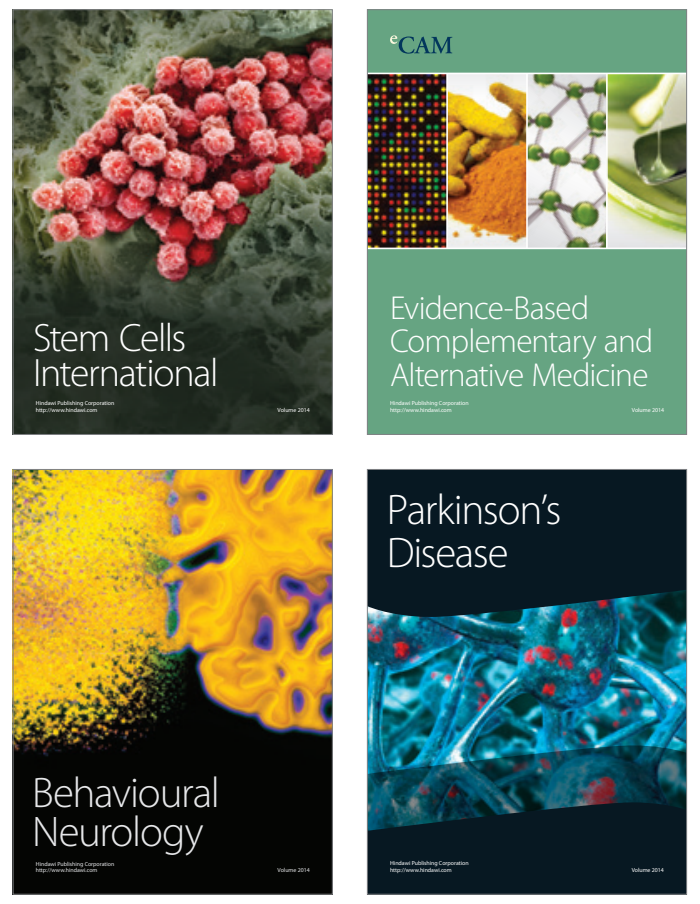
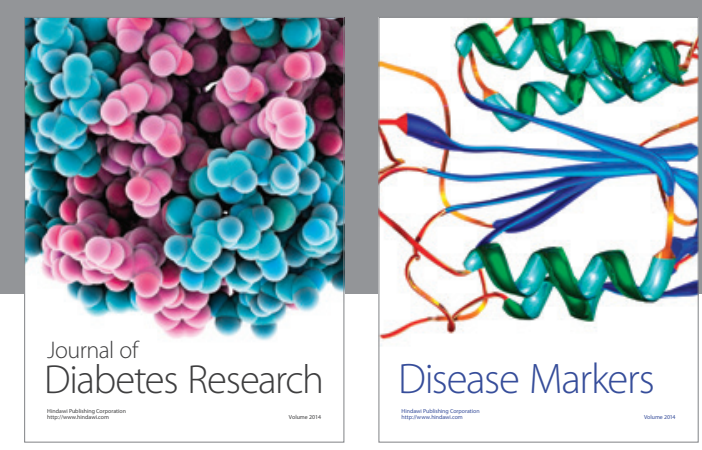

Disease Markers
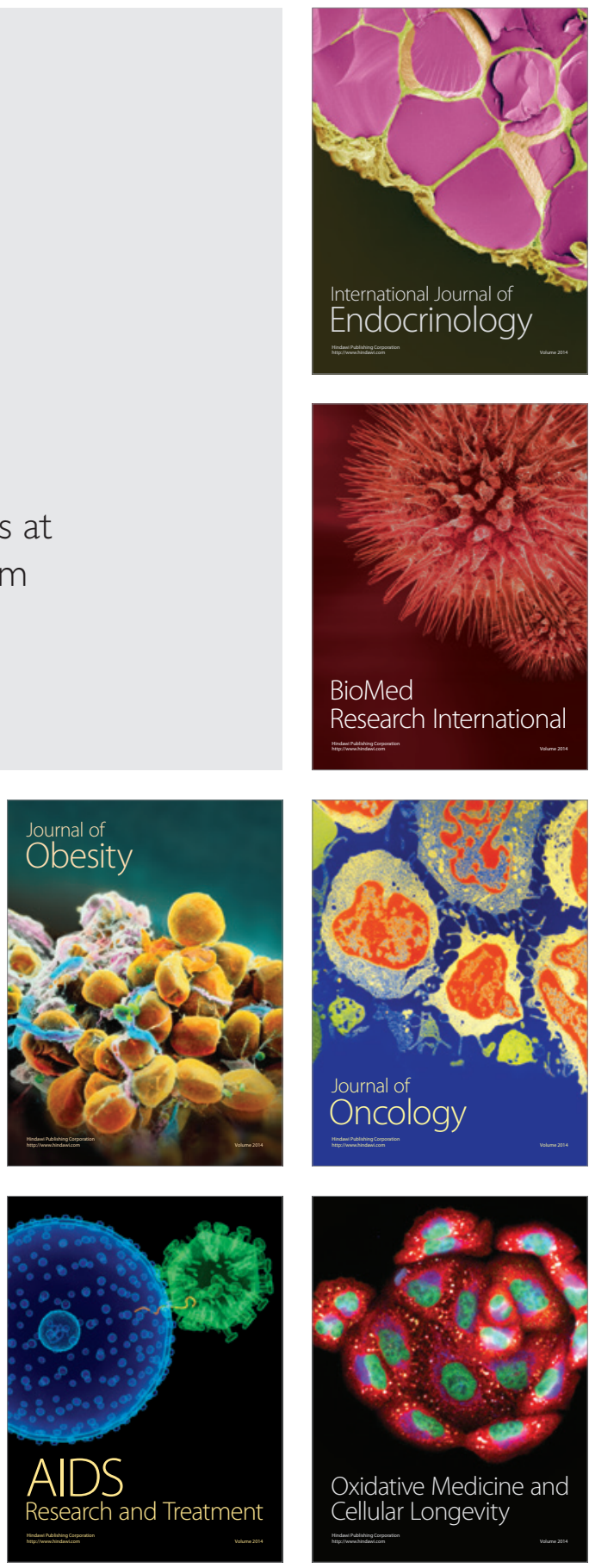